\title{
The History of the Military Film Industry - From the inception of military films to the ROK Army Motion Picture Production Center (1948-1979) -*
}

Sunyoung Park**

\section{Introduction}

In this paper, I examine the history of the Republic of Korea (ROK) Army Motion Picture Production Center, which was an important pillar of the Korean film industry from the 1950s and 1970s. ${ }^{1}$ During this time, the Army Motion Picture Production Center was South Korea's official film production company, along with the National Film Production Center, and produced various news reels, culture (munhwa) films, and fiction films. Starting with the first Korean War documentary films An Assault of Justice (1951) and National Defense News (1952), the Army Motion Picture Production Center produced an average of over 100 films every year, including numerous educational short films and feature-length fiction

* This study was supported by the Ministry of Education of the Republic of Korea and the National Research Foundation of Korea (NRF-2016S1A5B5A01026049).

** Researcher, Research Center of Korean History, Korea University, Seoul.

1 This study aims to examine the time period from the $1950 \mathrm{~s}$ to the $1970 \mathrm{~s}$. As the name of the organization that was used until the last of its days was the ROK Army Motion Picture Production Center of the Ministry of National Defense, the organization will be referred to as the "ROK Army Motion Picture Production Center" in this paper for simplicity's sake. The changes in the organizational structure and the name of the organization will be discussed in detail later in this paper. 
films. In addition, important figures of the Korean film industry, such as Han Hyŏngmo, Kim Haksŏng, Yang Chunam, Kim Suyong, Yi Manhŭi, and Shin Pongsŭng, have either been affiliated or had close relationships with the center. For instance, Director Han Hyŏngmo was the person who organized the filming crew at the Ministry of National Defense during the Korean War; Director Kim Suyong started his career in film by directing a military film; Director Yi Manhŭi was commissioned by the Army Motion Picture Production Center to direct three commercial feature films about wars. Not only directors but also people in film editing, scripts, and other areas of film were active in Korea's mainstream film industry and the Army Motion Picture Production Center. This means that between the 1950s and 1970s, the AMPPC had a close relationship with the Korean film industry in terms of the quantity and quality of films, as well as the personnel and physical infrastructure. In consideration of these facts, it is necessary to reevaluate the history and films produced by the AMPPC from historical and industrial points of view.

Unfortunately, despite the historical, cultural, and industrial importance, the films produced by the AMPPC have not been discussed systematically. The biggest reason has been the difficulty in accessing the films produced by the AMPPC. With the exception of a few fiction films that are uploaded on the Korean Film Archive's Film Library, most culture films, educational films, and the National Defense News, which accounted for the largest portion of the AMPPC's film production, had been produced as films and housed at the Ministry of National Defense, which was not easily accessible for the public. Second, there was not enough material to establish the history of military films, and no one recognized the need to study them. Particularly after the AMPPC was incorporated into the Army Promotion Management Center and the National Defense News began to air on TV, the Korean military's film production was reduced considerably, and in this process a significant number of documents and records related to the military's film production seems to have been lost. Currently, the National Archives of Korea has about 500 records related to military films from this time period, and the Korean Film Archive stores 
about 50 censorship records. However, these are only a small amount of the total number of films that had been produced. For these reasons, academia also has showed no interest in military films. In the study of Korean film history, interest in non-fiction films began relatively late. While films that had been created by the National Film Production Center and Liberty Production and were affiliated with the United States Information Service (USIS) have been actively discussed and examined so far, military films have never been systematically researched. ${ }^{2}$ Even in the study of military history, there has been a lack of research in film and media. Only recently, papers on radio broadcasts and proposals for the vitalization of the Korean Forces Network (KFN) TV have been published. ${ }^{3}$ Until now, only two publications on the history of the AAMPC have been released: The Forty-year History of Military Films (Kunyŏnghwa sasimnyŏnsa) ${ }^{4}$ and The 65 Years of National Defense Promotion (Kukpang

2 Park Sun Young, 'P'ŭreim sok-ŭi chŏnjaeng: kungnip yŏnghwa chejakso-wa kukkun yŏnghwa chejakso-ŭi Bet'ŭnam chŏnjaeng yŏnghwa-rŭl chungshimŭro (A war in the frame: focusing on the films about the Vietnam War produced by the National Film Production Center and the ROK Army Motion Picture Production Center)" in Yŏngsang-kwa akaibing kŭrigo saeroun yŏksa ssŭgi (Videos, archiving, and the writing of a new history), ed. Hŏ Ǔn (Seoul: Tosŏch'ulp'an Sŏnin, 2015) is the only study that mentions the history of the ROK Army Motion Picture Production Center.

3 Yi Shinjae, “Chuwŏl Han'gukkun pangsongguk (KFVN) ŭi sŏlch'i-wa unyŏng (A study on the establishment and operation of the Korean Forces Vietnam Network)," Kunsa (Military History) 92 (September 2014); Ch'a Ch'anghun, "Kukkunbangsong (KFN) midiǒ hwaryongbangan yŏn'gu: chanbyŏnggyoyuk, wigidaeŭngch'aek, chŏngch'aekhongbo unyŏngbangan-ŭl chungshimŭro (A study on the use of the Korea Forces Network media: focusing on the operation of soldier training, emergency response, and policy promotion activities)" (MA Thesis., Korea University, 2014); Kim Chongmyŏng, "2006-2010nyŏn kukkunpangsong TV 5nyŏn-e taehan p'yŏngga-wa che'an (An evaluation of Korean KFN TV's performance from 2006 to 2010 and suggestions for its future development" (MA Thesis., Dankuk University, 2011).

4 Kukpangbuhongbogwalliso (Defense Media Management Center), Kunyŏnghwa sasimnyŏnsa (The Forty-year History of Military Films) (Seoul: Kukpangbuhong- 
hongbo 65 nyŏnsa). ${ }^{5}$ Both publications were compiled by the Korean military, and mainly contain the memoirs of the people who participated in the production of the ROK Army films and a summary of the history of the AMPPC based on the memoirs. However, neither was based on empirical documents, and therefore are unable to present a complete history of the AMPPC. The timeline on the official website of the Defense Media Agency also reflects a similar lack of information, as it did not even incorporate the results of The Fifty-year History of Troop Information and Education (Chŏnghun osimnyŏnsa), published by the Office of Troop Information and Education of the Republic of Korea Army Headquarters. ${ }^{6}$ Furthermore, even the timelines published in The Chronology of Military Films: 1950-1994 (Kunyŏnghwa p'yŏllam: 1950-1994) ${ }^{7}$ and The Fortyyear History of Military Films (Kunyŏnghwa sasimnyŏnsa) show significant differences.

In the 2010s, some of the physical conditions that enabled research on military films began to be created. Since 2012, the Defense Media Agency gradually began to digitize the films produced by the AMPPC and provide access to them on its website (http://tv.dema.mil.kr/web/tv/ma in.do), and a considerable number of them are currently available online. In addition, Korea University's Center for Korean History collaborated with the Korean Film Archive to create a database of videos and films in modern and contemporary history, through which over 300 episodes of Defense News have been uploaded along with cataloging information on

bogwalliso (Defense Media Management Center), 1992).

5 Kukpanghongbowŏn (Defense Media Agency), Kukpang hongbo 65nyŏnsa (The 65 Years of National Defense Promotion), (Seoul: Kukpanghongbowŏn (Defense Media Agency), 2015).

6 Kukpangbuhongbogwalliso, Kunyŏnghwa sasimnyŏnsa (The Forty-year History of Military Films),(Seoul: Kukpangbuhongbogwalliso (Defense Media Management Center), 1992).

7 Kukpangbuhongbogwalliso, Kunyŏnghwa p'yŏllam: 1950-1994 (The Chronology of Military Films: 1950-1994) (Seoul, Kukpangbuhongbogwalliso (Defense Media Management Center), 1997). 
the Modern and Contemporary Korean Historical Film Archive website (http://kfilm.khistory.org). These advancements have paved the way for a systematic approach to the films and videos produced by the AMPPC.

As a basic research to study these videos and films, this paper aims to recount the history of the AMPPC based on empirical information. To this end, I first compare and contrast the timelines and documents compiled by the Defense Media Agency, including The Forty-year History of Military Films, The Chronology of Military Films: 1950-1994, The Fiftyyear History of Troop Information and Education, and History of Changes in the National Defense Policy (Kukpang chŏngch'aek pyŏnch'ŏnsa). Then I use newspapers, periodicals, film advertisements, documents on military film production as well as oral resources to reorganize the timeline of existing history. These are supported and confirmed by video resources when necessary. This is a restoration of a part of Korean film history that has been kept hidden until now, and will also provide a foundation to study the role and significance of military films as a means for Korea to wage a type of psychological warfare on its own people.

\section{Military Films from the Establishment of an Independent South Korean Government in 1948 to Before the Korean War in 1950}

Forty-year History of Military Films, 65 Years of National Defense Promotion, and the Defense Media Agency website state that the history of military film production began with the Korean War, which began on June 25, 1950. In particular, the books documented that the Troop Information and Training Bureau (chonghun'guk) was established during the war in 1950 by people in film such as Han Hyŏngmo. However, the Troop Information and Training Bureau was already in existence at the time the Korean army was founded, and military films were being filmed prior to the war.

After the government of the Republic of Korea was founded on August 
15, 1948, the Ministry of National Defense commissioned the second bureau (Troop Information and Education Bureau) to be strictly in charge of troop information and education based on the Act on the Organization of National Armed Forces on November 29. The bureau also absorbed the tasks of the Military Press Department under the United States Army Military Government in Korea (USAMGIK). ${ }^{8}$ "Troop information and education" is a concept that incorporates all tasks related to troop information, troop education, and public information. ${ }^{9}$ Following the simplification of the Ministry of National Defense in May 1949, the Chief of Staff system was abolished, with the Minister of Defense taking charge of the army and the navy. The Army Headquarters was reorganized, and the Office of Troop Information and Education was newly established. As a result, the Troop Information and Education Bureau was dissolved and incorporated into the Army Headquarters' Office of Troop Information and Education, and Song Myŏnsu, who was the head of the Troop Information and Education Bureau, was reassigned as the head of Office of Troop Information and Education in the ROK Army. This, however, was simply a transfer of the tasks of the Troop Information and Education Bureau to the Army Headquarters. Therefore, on October 15, the Troop Information and Education Bureau was reinstalled, and the Army Headquarters' Office of Troop Information and Education was incorporated into it. Afterward, on April 5, 1950, the Army Headquarters' Office of Troop Information and Education was reestablished to strengthen military maneuvers related to troop information and education. ${ }^{10}$ During this time, due to the process of

8 Originally, the second bureau was going to be named the Political Bureau. However, Brigadier General Roberts of the Provisional Military Advisory Group (PMAG) of the US Armed Forces in Korea, Colonel Wright of the PMAG, and Captain Hausman absolutely objected against having a commissar, and thus the name was changed to the Troop Information and Education Bureau. Kukpanggunsayŏn'guso, Kukpang chŏngch'aek pyŏnch'ŏnsa (History of Changes in the National Defense Policy) (Seoul: kukpanggunsayŏn'guso, 1995), 34.

9 Kukpanggunsayŏn'guso, Kukpang chŏngch'aek pyŏnch 'ŏnsa, 34.

10 Yukkunbonbujŏnghun'gamshil, Chŏnghun osimnyŏnsa, 73-74. 
the creation and reorganization of the Troop Information and Education Bureau and Office of Troop Information and Education, the military activities were also dualized. Also, the organization that was actively involved in the film industry, from actual production to editing and sponsoring, was the Office of Troop Information and Education, which belonged to the ROK Army.

The first related article is entitled, "Military film production with premium mobilization" from October 1948. ${ }^{11}$ This article states that the Ministry of National Defense was planning to produce a film with the aim to "improve the importance of military defense and military thought" and that "Producer Kim Kwansu, screenwriter Kim Chŏnghyŏk, Director An Chinsang, and cameraman Yi Myŏngu" have joined the production team. However, although the article said that the film would be completed by the end of the year, there is no record of a movie produced by the Ministry of National Defense in 1948. The first military film that was actually produced and released was Operation Chirisan (Chirisan chakjŏn). An advertisement for the film published on Chayu shinmun on July 19, 1949, presented Operation Chirisan as a film "produced by the ROK Army Headquarters' Operation and Education Bureau and filmed by the Film Unit of the Military Press Department with determination." 12 In November 1948, there was already a special news report on Korean films sponsored by the Ministry of Internal Affairs and the Ministry of National Defense, ${ }^{13}$ but this was the first film that was stated in a newspaper as

11 "Kukpang yŏnghwa chejak illyusŭt'ap tongwŏnŭro (Military film production with premium mobilization)," Kyŏnghyang shinmun (Kyunghyang Shinmun), Evening edition, October 12, 1948. 3.

12 "Advertisement," Chayu shinmun, July 19, 1949.2.

13 "Advertisement," Chayu shinmun, November 5, 1948. 4. This advertisement says "Choyŏng's specially dispatched Media Reporting and Filming Unit/Kim Haksŏng and Shim Chaehŭng devotedly films on location." Choyŏng is short for Chosŏn yŏnghwasa (Korean Film Company) and considering that the film was "simultaneously released" in four theaters (Sudo, Kukdo, Seoul, and Chungang), it is clear that this film was very important. In the Korean Film Archive's database (KMDb), 
having been directly produced by the military. This film- "Watch! The tragic end of the cruel and inhumane rioters Kim Chihoe and Hong Sunsŏk!! The image of Kim Chihoe's wife Cho Kyŏngsun who was captured by the Korean army" - was a feature-length record film about the Yŏsu-Sunch'ŏn Incident. ${ }^{14}$ The government immediately sent the military to crack down on the rebellion, which erupted within two months of the founding of the government of the Republic of Korea. Concerned about the worsening press and criticism from outside Korea, the Korean government decided to change the operation from a harsh crackdown to a stronger pacification campaign alongside the crackdown starting in midDecember. ${ }^{15}$ Operation Chirisan, which was produced at a time when the "pacification campaign [was becoming] systematized,"16 used the real names of the rebellion army's commander-in-chief Hong Sunsŏk and chief of staff Kim Chihoe to announce the completion of the suppression of the rebellion and conclude the press work. In the same context, the Morning of Cheju Island, another feature-length cultural documentary film that was advertised as having been planned and provided by the Ministry of Internal Affairs and sponsored by the Korean Army Headquarters' Operation and Education Bureau was also subtitled, "The suppression of the so-called Cheju Incident." The film was produced for propaganda after the Cheju April 3rd Incident, and the Army Headquarters' Office of

there is data on Yŏsu-Sunch'ŏn pallan sagŏn (Yŏsu-Sunch'ŏn rebellion), which was produced by Chungang yŏnghwasa (Chungang Film Company), sponsored by the Ministry of Internal Affairs and the Ministry of National Defense, and released on November 15, 1948. It is impossible to tell if the two films are one and the same.

14 "Advertisement," Tonga ilbo (Dong-A Ilbo), July 18, 1949. 2. This advertisement exclusively released in Seoul Theater starting on the 20th.

15 Im Songja, "Yǒsunsagŏn ihu sŏnmugongjak-ŭl chungshimŭro pon Chirisanjigu-ŭi ppalch'isan chinap (Suppression of partisans in Mt. Jiri District: focusing on the placation maneuver after the Yŏsun Incident)," Han'guk kŭnhyŏndaesa yŏn'gu (Journal of Korean Modern and Contemporary History) 81 (June 2017): 199-200.

16 Im, "Yŏsunsagŏn ihu sŏnmugongjak-ŭl chungshimŭro pon Chirisanjigu-ŭi ppalch'isan chinap," 200. 
Troop Information and Education sponsored it. The film North Korean Puppet Group News (The situation in North Korea), which was filmed by the Counterintelligence Corps of the Army Headquarters' Information Bureau, released by the Press Department of the Army Headquarters' Office of Troop Information and Education, and opened in Kukdo Theater and City Theater on October 12, 1949, was another film produced by the Army Headquarters during this time. ${ }^{17}$

There are two fiction films produced by the ROK Army around this time as well. For the Country, which became the talk of the town for having been "planned and produced by the Army Headquarters' Operation and Education Bureau" and "starring the ROK Army executives" was the first military fiction film created in the Republic of Korea and was advertised for "simultaneous release in four theaters" on October 5, 1949. ${ }^{18} \mathrm{~A}$ dramatization of an event that took place on the front lines, the film mostly recorded real soldiers and was endorsed for having been "praised by some filmmakers and artists." 19 For the Country was introduced as a "battle film" about the struggles and love of soldiers in a "punitive expedition against the communists in Mount Chiri." It was jointly directed by An Chonghwa and Sŏ Chŏnggyu, starred Kong Kukchin, Yi Hŭisuk, Min Hyeryŏn, Yi Wŏnch'o, and Ko Sŏnae, and involved a number of skilled workers in the film industry, such as Kim Sŏngch'un for lighting, Yang Chunam for editing, and Cho Paekpong. ${ }^{20}$ Among them, Kong Kukchin,

17 “Advertisement,” Kyŏnghyang shinmun (Kyunghyang Shinmun), October 12, 1949. 2.

18 In reality, the film was simultaneously released in three theaters-Sudo Theater, Sŏul Theater, and City Theater.

19 "Advertisement," Kyŏnghyang shinmun (Kyunghyang Shinmun), September 22, 1949. 2.

20 The synopses and information on the production staff have been gathered from $\mathrm{KMDb}$, according to which the person in charge of producing and planning the film was Kim Kwansu. Kim was already mentioned as a producer of the films produced by the Ministry of National Defense noted in the newspaper advertisement in footnote 11 . 
who played the lead role, was a major on active duty at the time. ${ }^{21}$ In the same year, Breaking the Wall (Han Hyŏngmo) was produced and promoted as a "Fifth Infantry Division's Third Regiment" production. ${ }^{22}$ A film about the conflict between two college friends who became brothers-inlaw and were destined to face each other as a communist and a second lieutenant of the ROK Army "during the Yŏsu-Sunch'ŏn Incident" 23 Breaking the Wall was released at the Chungang Theater on October 17 and advertised as a "film that stood shoulder to shoulder with films around the world." This film was also the debut film directed by Han Hyŏngmo, who led the establishment of the military film unit during the war.

In this way, the ROK Army was in charge of the production of films focusing on "pacification" and "public communication" during the period in which the ROK Army was founded. The Army not only created newsreels, such as North Korean Puppet Group News, and feature-length documentaries, including Operation Chirisan and Morning of Cheju Island, but also feature-length fiction films, such as For the Country and Breaking the Wall. ${ }^{24}$ Another characteristic of the films involving the military at this time was that most involved the Yŏsu-Sunch'ŏn Incident, regardless of the film genre.

21 "For the Country (Nara-rŭl wihayŏ)," Kyŏnghyang shinmun, September 29, 1949. 2.

22 “Advertisement,” Kyŏnghyang shinmun, September 3, 1949. 1.

23 Refer to KMDb for the synopsis. The record that the Korean Army produced Breaking the Wall can also be found on p. 84 of Yukkunbonbujŏnghun'gamshil, Chŏnghun osimnyŏnsa (The Fifty-year History of Troop Information and Education), but this record mentions the 3rd Regiment of the Army 8th Division

24 There are also records of the military cooperating in the film production of a private film company. The Army Headquarters' Aviation Command was in charge of reviewing the film Pilot An Chang-Nam (An Ch'angnam pihaengsa) (No P'il, 1949) (refer to KMDb). The Army Headquarters' Aviation Command was reshuffled into the Air Force after the establishment of the Korean Air Force in October 1949. Kukpanggunsayŏn'guso, Kukpang chŏngch'aek pyŏnch'ŏnsa (1945-1994) (History of Changes in the National Defense Policy, 1945-1994), 41. 


\section{The Korean War and Military Films of the 1950s}

1. The Establishment of the Film Unit at the Troop Information and Education Bureau and the Founding of the Military Motion Picture Production Center

After the Korean War broke out in 1950, the Troop Information and Education Bureau of the Ministry of National Defenses absorbed and integrated the Army Headquarters' Office of Troop Information and Education for more systematic and efficient troop information and training activities. With a fundamental reorganization of the Army Headquarters in January 1951, the Office of Troop Information and Education was separated once again from the Troop Information and Education Bureau at the Ministry of National Defense and expanded. Throughout the 1950s, both the Ministry of National Defense's Troop Information and Education Bureau and the Army Headquarters' Office of Troop Information and Education were in operation. The Troop Information and Education Bureau's Press Department consisted of the "Film Unit, Photography Unit, Reporting Unit, and Censorship Unit." At the same time, the Troop Information and Education Bureau's Strategy Department had a Pusan Office and Front-Line Office, and the latter had a Reporting Corps, which was divided into a Photography Team and Film Team, and these groups were in charge of related activities. ${ }^{25}$ According to the operational regulations of the Troop Information and Education Bureau in war time, the Film Unit was in charge of 1 . Items related to the planning of the film shooting; 2. Items related to the storage of films and film equipment; 3 . Items related to the development, organization, and distribution of films; 4. Items related to the guidance of filming skills (actors and technicians); and 5. Items related to other institutions' filming guidance and restrictions. ${ }^{26}$ Film related tasks by the Army Headquarters' Office of Troop Information and Education were assigned to the "Film Section" within the Press Depart-

25 Yukkunbonbujŏnghun'gamshil, Chŏnghun osimnyŏnsa, 119.

26 Yukkunbonbujŏnghun'gamshil, Chŏnghun osimnyŏnsa, 122. 
ment. According to the regulations of the Office of Troop Information and Education, the tasks of the Film Section were: 1. Filming of documentaries on battles and army's relations; 2. Photography for propaganda and reporting materials; and 3. Items about film production. ${ }^{27}$ The Army Headquarters' Film Section was not only in charge of films and photography but also the filming of battles, which were mainly undertaken by the Army Headquarters. ${ }^{28}$

At a time when many cultural artists were going to the military, becoming military writers, military painters, and military entertainers, people in the Korean film industry also joined the bandwagon with the establishment of the Filming Corps in the Press Department of the Troop Information and Education Bureau immediately after the Korean War broke out. Han Hyŏngmo, Kim Kwansu, Kim Poch'ŏl, and Kim Chonghwan accompanied the military to the Inch'ŏn landing operation, and used films from various struggles and seized articles they received from the Army Headquarters Operational Education Bureau to "create a laboratory with primitive and deficient facilities to start the development activities." The film, An Assault of Justice (Chŏngŭi-ŭi chin'gyŏk), whose sound was recorded in Japan after editing, was released and screened on June 20, 1951 at Chayu Theater in Taegu and Tonga Theater in Pusan, while part two of the same movie was screened in Pusan on February 5, 1952. ${ }^{29}$

The Film Unit of the Press Department of the Troop Information and Education Bureau was promoted to the Military Motion Picture Studio in January 1952. It began the production of the National Defense News, and

27 Yukkunbonbujŏnghun'gamshil, Chŏnghun osimnyŏnsa, 117-118.

28 There was an Office of Troop Information and Education in the Korean Air Force, where people from the film industry were involved. However, aside from Assail Order (Ch’ulgyŏk myŏngnyŏng) (Hong Sŏnggi, 1954), which was released after the war, no records have been found regarding the production of other films. The Korean Navy also had a film unit led by Yi P'iru, but there are no records about any films either. Yi Yŏngil, Han'guk yŏnghwa chŏnsa (A complete history of Korean films) (revised and enlarged edition) (Seoul: Tosŏch'ulp'an Sodo, 2004), 228

29 Yukkunbonbujŏnghun'gamshil, Chŏnghun osimnyŏnsa, 212-213. 
the first episode was completed on June 22, 1952. Around this time, the Military Motion Picture Studio worked in collaboration with the Collaborative Motion Picture Production Center in Chinhae. ${ }^{30}$ The first person to take charge of the Military Motion Picture Studio was Major Yun Ponghŭi. ${ }^{31}$ In addition, each military unit also performed film-related troop information and education activities. For instance, the Film Section of the 3rd Infantry Regiment signed a contract with Taegu's Man'gyŏnggwan Theater to screen $16 \mathrm{~mm}$ Korean films (purchased a 16 $\mathrm{mm}$ projector as regiment equipment), and the 37th Infantry Regiment purchased a projector and rented National Defense News, Liberty News, and other culture films as well as educational films to screen them at least once a month at the regiment headquarters and at each battalion. ${ }^{32}$

Meanwhile, the production and release of the Marine Battle Group's film Rifles and Swords (Cho Inbok, 1953) was mentioned immediately

30 The Han'guk yŏnghwa chŏnsa records the organization as Haptong yŏnghwasa (Collaborative Motion Picture Production Company), but the official name is "Hyŏpt'ong yŏnghwa chejakso" (Collaborative Motion Picture Production Center). Due to the conflict with people from the U.S. Information Service regarding the sound recording for An Assault on Justice, Korean film professionals who were affiliated with the U.S.I.S. quit and renovated the bathhouse managed by the Korean Naval Academy to install a developing studio and a recording studio to set up the Collaborative Motion Picture Production Center. Shim, Hyegyŏng, "Chuhanmigongbowŏn yŏnghwagwa-ŭi chejak hwan'gyŏng-gwa hwaryakhan Han'guk yŏnghwain-dŭl: haebang-esŏbutŏ 1960nyŏndaekkaji (The production environment of the US Information Service' Film Department and the Koreans Who Played an Active Part: from Korea's liberation to the 1960s)" in Han'guk yŏngsang charyowŏn 2011nyŏn sujippogwŏnchŏn charyojip: naengjŏn shidae Han'guk-ŭi

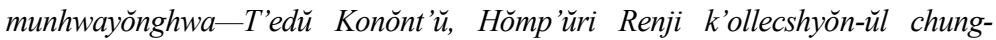
shimüro (Sourcebook of the Korean Film Archive's 2011 Collection and Restoration Exhibition: Korean culture films during the Cold War-focusing on the Ted Conant and Humphrey Leynse collections)(Seoul: Han'guk yŏngsang charyowŏn (Korean Film Archive), 2011).

31 Kukpangbuhongbogwalliso, Kunyŏnghwa sasimnyŏnsa, 12.

32 Yukkunbonbujŏnghun'gamshil, Chŏnghun osimnyŏnsa, 272-277. 
prior to the armistice. Including "actual footage of intense battles with the communist Chinese troops" since November 1952, the film was produced by the Far East Film Company (Kŭktong Yŏnghwasa) and directed by Captain Cho Inbok, starring Yun Ilbong and Kim Suyang. ${ }^{33} \mathrm{KMDb}$ categorized this film as a semi-documentary, with actual footage from battles but reenacted battle scenes. According to Yu Tuyŏng, the Marine Corps produced and released another film entitled, The Record of Victory (Sŭngni-ŭi kirok) in the same year as Rifles and Swords, but there are no accurate records of the film. Moreover, Comprehensive News (Chonghap nyusŭ), a newsreel produced by the Korean Army Communications and Photography Corps, and the documentary The Long Way Home (Sŏbu chŏnsŏn), produced by the 15th Regiment of the 1st Division of the Korean Army, are military films that were produced during the Korean War. ${ }^{34}$ Among them, Comprehensive News was produced in Taegu before the government's return to the capital but ultimately stopped due to the lack of equipment and facilities as well as overlap with National Defense News and Liberty News. ${ }^{35}$ Lastly, The Artillery School (Yukkun p'obyŏng hakkyo) (Pang Üisŏk, 1951), produced by the Enlightenment Cultural Association (Kyemong munhwa hyŏphoe), is a documentary about the daily activities of the Artillery School, and it was submitted to the Korean

33 "Completed the documentary film on the marine battle scenes-Rifles and Swords (Ch'onggŏm-ŭn saraitta)," Kyŏnghyang shinmun (Kyunghyang Shinmun), July 13, 1953. 2. This article mentions that the film was produced with the "help of marine battle groups," but there is no mention of the marines in KMDb. However, given that Cho Inbok, who was a captain of the marines, was in charge of the film and the review from Yu Tuyŏn, it seems reasonable to say that this film was produced by the ROK Marines.

34 Yu Tuyŏn, “Hoego-wa ch'ŏngsan/p'inan 3nyŏn'gan-ŭi munhwa undong (sang) yŏnghwa (Remembrance and settlement/cultural movement films during the three years of war," Kyŏnghyang shinmun (Kyunghyang Shinmun), November 12, 1953. According to KMDb, The Long Way Home (1951) is a documentary produced by the 15th Regiment of the 1st Army Division. Its director was Yun Pongch'un and producer was the Enlightenment Cultural Association.

35 Yukkunbonbujŏnghun'gamshil, Chŏnghun osimnyŏnsa, 403. 
Army after production.

\section{Completion of the ROK Army Motion Picture Production Center (AMPPC)} after the War and the Production of "Educational Films"

After the ceasefire was signed on July 17 to put a stop to the Korean War, 1953, the Troop Information and Education Bureau was reduced to the Troop Information and Education Division and became an organization that was directly under the auspices of the minister. Military film production activities had been promoted to the Military Motion Picture Studio in 1952 but was reduced again to the Film Department of the Troop Information and Education Division, which was located in P'ildong in Chunggu, Seoul. Then with the promulgation of the Government Organization Act in February, the Troop Information and Education Division became reinstalled as the Troop Information and Education Bureau, and the Film Department was renamed to a military film studio. ${ }^{36}$ According to an article entitled the "Current Status of the Korean Film Industry" from August 1954, the film production facilities that were usable in the film industry at the time were facilities that belonged to the Ministry of National Defense and the Bureau of Public Information. The Ministry of National Defense had one $35 \mathrm{~mm}$ video camera, six $16 \mathrm{~mm}$ cameras, and one print film developer. ${ }^{37}$ The Korean military, which continued film production during the

36 Kukpangbuhongbogwalliso, Kunyŏnghwa sasimnyŏnsa, 15. The Military Motion Picture Studio during the war or the Film Department of the Troop Information and Education Bureau and the military film studio had been spearheaded by the Korean Army's majors, lieutenant colonels, or colonels. After Colonel Chon Il, the second director of the center, followed by Colonel Han Hŭiyŏl and Lieutenant Colonel Hyŏn Tujŏng. In 1955, the Military Motion Picture Studio's director was Colonel Yi Chongt'ae. Yukkunbonbujŏnghun'gamshil, Chŏnghun osimnyŏnsa, 298.

37 "Han'guk yŏnghwagye-ŭi hyŏnhwang (Status of the Korean film industry)," Hankuk ilbo, August 2, 1954. 4. 
wartime when most film infrastructure had been destroyed, was one of the few facilities that provided a shoulder to rely on for the Korean film industry after the war. One noteworthy point is that the Film Department of the Ministry of National Defense completed a film production center during the time, where film developing, editing, sound recording, and subtitling were possible. The Motion Picture Production Center, which began construction in September 1954, was completed in July 1955 with a sound recording room and an RCA recorder, development room with necessary equipment, and editing room. The inauguration ceremony for the center was held on September $1 .^{38}$ Finally equipped with postproduction facilities, the Military Motion Picture Production Center expressed its ambition to produce two culture films and two National Defense News episodes to strengthen the solidarity between the front lines and back lines. ${ }^{39}$ However, since the whole film production system in Korea had fallen behind, the AMPPC was in poor condition having to rely on skilled technicians even though the Motion Picture Production Center was equipped with postproduction facilities. The center provided facilities for film development, sound recording, and editing, as well as technical support for 70 to 80 percent of Korean films. $^{40}$

Among the films that were produced in the 1950s, the first notable one is the National Defense News. The National Defense News was produced for four years in the 1950s, and then it began to be re-produced in 1966, starting with the first episode, and has continued until today as TV National Defense News. The films discussed

38 Yukkunbonbujŏnghun'gamshil, Chŏnghun osimnyŏnsa, 364; Kukpangbuhongbogwalliso, Kunyŏnghwa sasimnyŏnsa, 528.

39 "Maewŏl munhwa yŏnghwa 2 p'yŏn kukpangbusŏ chejakkyehoek (Defense Ministry to produce two culture films a month)," Kyŏnghyang shinmun, October 30, 1955. 4.

40 Yang Hŭich'ŏl, “Han'guk yŏnghwa palchŏn-ŭi ch'osŏk (The cornerstone of the development of Korean Cinema) in Kunyŏnghwa sasimnyŏnsa, 95-96. 
in this paper are the National Defense News from the 1950s. As mentioned above, the very first episode of National Defense News was produced on June 22, 1952. According to the Forty-year History of Military Films, the very last episode was no. 66, produced on May 18, $1956 .{ }^{41}$ However, the Modern and Contemporary Korean Historical Film Archive website lists National Defense News no. 75, which includes the ceremony of the first Armed Forces Day; the arrival of Randolph Pate, the Commandant of the U.S. Marine Corps, on October 1, 1956; and the ceremony for the third anniversary of the founding of the Fifth Army Corps held on October 18,1956 . Therefore, from the remaining films, it would be reasonable to estimate that there were a total of 75 episodes of the $\mathrm{Na}$ tional Defense News of the 1950s, with the last episode produced in October 1956.

Meanwhile, on September 25, 1956, the Chosŏn Ilbo reported that a premier of "the first full-color National Defense News" would be held. ${ }^{42}$ Since all films of National Defense News, including episodes 70 to 75 , are assumed to be black and white, it is not possible to confirm that there is a "first full-color [news film] produced with Korean facilities and technology." However, considering the fact that color films have not often been produced in the 1950s aside from A Diary of Woman (Yǒsŏngilgi) (Hong Sŏnggi, 1949), the very first recorded color film in Korean film history, it would be important to remember that technical experiments with films had continued at the time through the National Defense

41 Kukpangbuhongbogwalliso, Kunyŏnghwa sasimnyŏnsa, 16. Since Chŏnghun taegye (Outline of troop information and education) (Troop Information and Education Bureau of the Ministry of National Defense, 1956), was published in 1956, the last National Defense News mentioned in the book was episode 66. Therefore this error seems to have resulted from other records using this book as the basis.

42 "25il-e shido/saekch'e nyusŭ yŏnghwa (A color new film to be tried on 25th)," Chosŏn ilbo (Chosun Ilbo), September 25, 1956. 2. 
News. ${ }^{43}$

In The Fifty-year History of Troop Information and Education (Chŏnghun oshimnyŏnsa), there is a record about the military producing army news entitled Our Army, and screening them for the people. As of 1955, there were nine episodes. It seems that Our Army had been created to introduce the Korean Army to the people after the Korean War regarding the Army's active part in the war, ${ }^{44}$ and was produced intermittently until the late 1950s. Considering that a major characteristic of "news" is timeliness, the Our Army series is more of a documentary or a cultural film than news. According to the records of the Korean Army's Information and News Center, the center produced two films that introduced the development of the Korean Army every month, two Army newsreels a month, and a fictional military film in 1956; six culture films that introduced the Korean military and Army newsreels in 1957; and about six films that promoted the army in 1958 and 1969. These films were distributed around Seoul and to theaters nationwide. ${ }^{45}$ Since there are no records on newsreels that were created by the Army Headquarters other than Our Army, it is highly likely that the Our Army series is the films mentioned in the records. The same series continued to be created in the $1960 \mathrm{ss}^{46}$

In addition, there were medium- to short-length films that were created as "educational films." According to the Forty-year Histo-

43 One film article from the Han'guk ilbo from 1956 stated, "the color documentary [produced by the Film Department of the Ministry of National Defense] was a short film, but it is worth going down on the record for providing the implications for the possibilities of full-color Korean films." "Kaet'anman hal kŏssŭn anida/1956nyŏn-gwa yŏnyegye (Not just for lamentations/the year 1956 and the entertainment industry)" Hankuk ilbo (Hankook Ilbo), December 31, 1956. 4.

44 Yukkunbonbujŏnghun'gamshil, Chŏnghun osimnyŏnsa, 403.

45 Yukkunbonbujŏnghun'gamshil, Chŏnghun osimnyŏnsa, 395-398.

46 Yukkunbonbujŏnghun'gamshil, Chŏnghun osimnyŏnsa, 603. The production process of Our Army from the 1960s will be discussed in detail in the next section. 
ry of Military Films, a total of 12 films were produced in the 1950s: ${ }^{47}$ Never Forget June 25 (Itchimalcha yuk io) (Kim Suyong, 1954), Memoirs of First Sergeant Yun (Yunjungsa-ŭi sugi) (Kim Suyong, 1955), A Ten-minute Break (Shipbun'gan hyushik) (Kim Suyong, 1956), Ode to the Motherland (Choguk ch'an'ga) (Kim Suyong, 1956), People of Ǔiyongch'on (Ǔiyongch'on saramdŭl) (1957), The Way of Soldiers (Kunin-ŭi kil) (1957), Sunrise Village (Haettŭ-nŭn maŭl) (Kim Suyong, 1958), Our Strength No. 1 (Uriŭi him ilho) (Kim Suyong, 1958), Sergeant Yi's Day Off (Yibyŏngjang-ŭi hyuga) (Yang Chu-nam, 1958), Our Strength No. 2 (Uri-ŭi him iho) (Yang Chunam, 1959), Our Strength No. 3 (Uri-ŭi him samho) (Yang Chunam, 1959), and A Visit from the Turkish Defense Minister (Toigi kukpangsang panghan kirok) (Yang Chunam, 1959). Among these, the Our Strength series are assumed to be newsreels, and up to 15 episodes were created by $1962 .{ }^{48}$ Aside from the Our Strength series and the newsreel about the Turkish Defense Minister's visit to Korea, a total of eight educational films were produced. Memoirs of First Sergeant Yun, directed by Kim Suyong, who was an army captain at the time, was released in public theaters in celebration of Christmas in 1955 . $^{49}$ Another article

47 According to Kunyŏnghwa p'yŏllam: 1950-1994, there are a total of five educational films created in the 1950s: People of Ǔiyongch'on (Ǔiyongch'on saramdŭl) (Yang Chunam, 1957); Private First Class Yun (Yun ildŭngbyŏng) (Kim Suyong, 1957); The Way of Soldiers (Kunin-ŭi kil) (Yang Chunam, 1957); Sunrise Village (Haettŭ-nŭn maŭl) (Kim Suyong, 1958); Sergeant Yi's Day Off (Yibyŏngjang-ŭi hyuga) (Yang Chu-nam, 1958). Among the five, Private First Class Yun (Yun ildŭngbyŏng) is the same film as Memoirs of First Sergeant Yun (Yunjungsa-ŭi sugi).

48 Our Strength episodes 10 and 14, produced in 1962, are currently housed at the Korean Film Archive 1.

49 "Yŏnghwa Yunjungsa-ǔi sugi, k'ŭrisŭmasŭ-rŭl kihae kaebong (Film Memoirs of First Sergeant Yun to be released in celebration of Christmas), Chosŏn ilbo, November 30, 1955. 3 . 
mentioned that Strength of Korea (Han'guk-ŭi him), a "military documentary film made by the Troop Information and Education Bureau," would be released nationwide "in celebration of the birthday of President Rhee," and the article also stated that the film "recorded the traces of the Korean military that has grown and developed after An Assault of Justice." Both Memoirs of First Sergeant Yun and Strength of Korea are notable in that they are circumstantial evidence of the fact that films produced by the Military Motion Picture Production Center were screened in general theaters. In addition, Ode to the Motherland is a film adaptation of the performance "Ode to the Motherland" put on by the Troop Information and Education Bureau in 1955, and it was remade into a cultural film entitled $A$ New Day Comes (original title: Ode to the Revolution) immediately after the May 16 military coup in $1961 .^{50}$

The Fifty-year History of Troop Information and Education estimates that a total of 20 education films had been created by 1956 . Aside from the films mentioned above, the list includes The Star of Million (Paengman-ŭi pyŏl), A Pledge to the Army (Kukkun maengse) (1954), Anti-Communist Prisoner of War (Pan'gong p'oro) (1954), Think about the Korean War (Saenggakhaja June

50 “Advertisement," Kyŏnghyang shinmun, June 22, 1955. 3. In Culture News on page 4 of Kyŏnghyang shinmun from July 1, 1955, there is an article about the film adaptation of Ode to the Motherland (Choguk ch'an'ga). The synopsis of the film is extremely similar to the National Film Production Center's culture film $A$ New Day is Coming (Sae narŭn pargaoda), which was planned as Ode to the Revolution (Hyŏngmyŏng ch'anga) immediately after the May 16 military coup in Korea, and the lyricist and the composer are the same (lyrics by Yang Myŏngmun, composed by Kim Tongjin). For the synioysis of A New Day is Coming, refer to "Munhwa yŏnghwa-ro ponŭn Taehanmin'guk (The Republic of Korea in Culture Films), Park Sun Young, "Sae narŭn pargaoda (A New Day is Coming) in Munhwa yŏnghwa-ro ponŭn Taehanmin'guk-1960nyŏndae chuyo munhwa yŏnghwa haesŏl (The Republic of Korea in Culture Films - commentary for major culture films of the 1960s)," National Archives of Korea, accessed November 28, 2018, http://theme.archive.go.kr.. 
25) (1954), Ceasefire is Not Peace (Hyujŏn-ŭn p'yŏnghwa-ga anida) (1954), Line of Peace (P'yŏnghwasŏn) (1954), The Collapsing Red People (Munŏjinŭn purgŭn kunsang) (1954), People Who Do Not Return (Toraoji annŭn saramdŭl) (1955), The Republic of Korea Army's Invitation of Free China (Chayu Chungguk Taehanmin'gukkun-ŭi cho'dae) (1955), Have You Forgotten? (Ijŏnnŭn'ga) (1955), Why Are You Only Watching (Wae pogoman innŭnga) (1955), Record of the Naval Academy's Training in the Open Sea (Haesa wŏnyang shilsŭp kirok) (1955), Star of the Mainland (Taeryuk-ŭi pyŏl) (1955), News from Home (Kohyangsoshik) (1956), and The Second Camp Gate (Che i-ŭi kunmun) (1956). These differences arise from the fact that while The Chronology of Military Films: 1950-1994 and The Forty-year History of Military Films tend to focus on the films that were produced by the Film Department of the Troop Information and Education Bureau, The Fifty-year History of Troop Information and Education also includes films that were produced by the Army Office of Troop Information and Education. Among the abovementioned films, The Star of Million (Yi Yongmin, 1954), directed by Kim Kwansu Production and which was introduced as a documentary about the various aspects of the 1st Training Institute in Cheju Island in KMDb was another educational film that the military podeuced. ${ }^{51}$

In addition, there is another article about the future production of a film entitled Who Should We Fight For? (Uri-nŭn nugu-rŭl wihayŏ ssawŏya hanŭn'ga), labeled as a "feature-length educational film," although no such film can be found in the records of military film history or chronology. ${ }^{52}$ These records are evidence of

51 Currently, the films of Line of Peace and People Who Do Not Return are housed at the Korean Film Archive. Refer to the KMDb.

52 “Changp'yŏn kyoyungyŏnghwa/Kukpangbu yŏnghwakwa chejak (Feature-length educational films/produced by the Film Department of the Ministry of National Defense)," Hankuk ilbo (Hankook Ilbo), January 10, 1957. 4. According to this ar- 
the Military Motion Picture Production Center's efforts in the production of various films at a time when feature-length film productions were made possible due to the establishment of a military film production center and the increase in personnel.

Lastly, there are several fiction films that were planned and sponsored by the military in the 1950s. Records indicate that The Road of Glory (Yŏnggwang-ŭi kil) (Yun Pongch'un, 1953), produced by Kyemong Yŏnghwasa, was sponsored by the 2nd Training Center of the Korean Army, while The Battle Line of Freedom (Chayu chŏnsŏn) (Kim Hong, 1955), was sponsored by the Army Headquarters and the Second Army Corps and recommended by the Ministry of National Defense and the Ministry of Education. ${ }^{53}$ In addition, Director Yi Kangch'ŏn's Beat Back (Kyŏkt'oe) (1956) was planned by the Army Headquarters' Office of Troop Information and Education and produced by Ch'óngnyong Production, ${ }^{54}$ and Director Yi Yongmin's A Cross in Gunfire (P'ohwasokŭi shipjaga) (1956) was also produced under the sponsorship of the Army Headquarters' Office of Troop Information and Education. ${ }^{55} \mathrm{As}$ sail Order (Ch'urgyŏk myŏngnyŏng) (Hong Sŏnggi, 1954), a "real battle film and the first aviation movie" produced with the cooperation of the Korean Air Force, The Flowing Star (Hŭrŭnŭn pyŏl) (Kim Muk, 1958), a melodrama produced with the cooperation of the Navy Headquarters, and the comedy A Dry-Bones and a Fatty Go To the Nonsan Training Station (Holchugi-wa ttungttung'i

ticle, the film production staff consisted of Director Kim Yong, Cameraman Im Sŏngdǒk, Assistant Cameraman Chang Sŏkchun, and soldiers.

53 "Shinyŏnghwa Chayu chŏnsŏn wansŏng (A new film The Battle Line of Freedom completed)," Kyŏnghyang shinmun, April 17, 1955. 4..

54 "Shinyŏnghwa Kyŏkt'oel Kihoek yukkunponbu chŏnghun'gamshik, chejak Ch'ŏngnyong p'ŭrotŏkshyŏn (New film Assail Order/ planned by the Office of Troop Information and Education at the Army Headquarters and produced by Ch'ŏngnyong Production)," Kyŏnghyang shinmun, January 13, 1956. 4.

55 Yukkunbonbujŏnghun'gamshil, Chŏnghun osimnyŏnsa, 404. 
Nonsan hunnyŏnso-e kada) (Kim Hwarang, 1959) are also worth being recorded as part of the history of military film production.

\section{The Establishment of the ROK Army Motion Picture Produc- tion Center (AMPPC) and the Diversification of Military Films (1960s to 1970s)}

1. Reorganization of the Military Film Production System and the Production of Television Films

Because there are more documents and videos from the 1960s and the 1970 s, the existing descriptions are relatively more trustworthy. In particular, after the reorganization of the Troop Information and Education $\mathrm{Bu}$ reau and the Army Headquarters' Office of Troop Information and Education in the 1960s, the AMPPC was mainly in charge of film related tasks until the 1970s, while the Army Headquarters' activities were reduced compared to the previous years. In this section, I would like to present a big picture of the reorganization of the system and related activities that followed, and continue the discussion with a focus on the films produced by the AMPPC.

First, looking at the reorganized system, according to the revision of the Government Organization Act based on Act no. 522 in July 1960, the Troop Information and Education Bureau was reorganized into the Troop Information and Education Department, Education Department, Press Department, and Special Forces Department. Then with the reorganization of the Ministry of National Defense in June 1962, the departments within the Troop Information and Education Bureau were expanded to the Strategy Department, Troop Information and Education Department, Press Department, Broadcasting Department, and Film Department. When the Troop Information and Education Department was reduced after 1963, the Troop Information and Education Bureau was renamed to the Troop Information and Education Liaison Bureau. The Broadcasting 
Department became the Military Broadcasting Office and the Film Department became the AMPPC and became independent entities. Then in July 1979, the AMPPC was temporarily integrated into the Military Promotion Management Center and completed in 1981. Between those years, military film-related activities were carried out by the AMPPC. ${ }^{56}$

The Army Headquarters' Troop Information and Education Office was reorganized to include the Administrative Office, Operations Office, Troop Information and Education Office, and General Education Office in 1959 and remained this way until 1965. Then in August 1965, the Troop Information and Education Department became the Troop Information, Education, and Training Department, and the General Education Department was renamed the Culture Department, which came to be in charge of film-related tasks at the Army Headquarters. This system, in which the Culture Department came to be in charge of films, was maintained without change in the future reorganizations as well. After the AMPPC was established at the Troop Information and Education Bureau, the Army Headquarters' film production was greatly reduced and mainly focused on the supply of films within the military and the screening of films. There were not enough projectors even in the 1960s that the AMPPC was in charge of screening the films that were produced by the National Film Production Center, the AMPPC, and other private companies within the military with a projector rented from the U.S. Information Service. ${ }^{57}$ Afterward, with the order to screen films at least twice every month in all military units, the number of projectors owned by the Army

56 Yukkunbonbujŏnghun'gamshil, Chŏnghun osimnyŏnsa, 555-557. In addition, the Vietnam Department was created in 1966 and abolished in 1970. Newspaper publication began with Chŏnu shinmun (Comradeship Newspaper) in 1964, and an independent office was built in 1979 and the Military Newspaper Production Center was established and reorganized. In 1975, the Military Spiritual Combat Power School was founded as part of the reorganization of the system, but there were no changes related to the ROK Army Motion Picture Production Center until the 1970s, and therefore this paper will not mention the changes in the center further.

57 Yukkunbonbujŏnghun'gamshil, Chŏnghun osimnyŏnsa, 582-583. 
units was increased to surpass the demand in 1975.

There was a film series that the Korean Army continued to create during this time, when film production was not particularly vibrant. It was Our Army (Uri-ŭi yukkun), a "documentary series about the army that introduces major events occurring within and outside of the military, educational training, and daily lives of soldiers to Koreans and foreigners." As mentioned above, Our Army, which began to be produced intermittently in 1955 was more regularly produced in the 1960s-about four episodes every year. ${ }^{58}$ However, the series was no longer created regularly in the 1970s. Instead, the episodes were produced as 20-minute short films in 1975, and they were first released to 30 theaters in the Seoul area and distributed to regional theaters. These short films were also aired on terrestrial television channels, including $\mathrm{KBS}, \mathrm{MBC}$, and $\mathrm{TBC}$ as special programs for the New Year. ${ }^{59}$

In the 1970 s, there were quite a few military films that were created for theater releases but also as television films. Not only the Our Army mentioned above, but also documentary films, such as $A$ Day at the Ceasefire Line (Hyujŏnsŏn-ŭi haru) and A Peaceful Flagbearer (P'yŏnghwa-ŭi kisu) were aired on television as part of the New Year programming. There were also series that have been created as television films. In 1975, the television film Fellow Soldiers (Chŏnu), planned by the Ministry of National Defense and supported by the ROK Arm, was produced. Produced for special programming around the anniversary of the Korean War in 1975 , the series was aired on KBS every week until $1978 .^{60}$ It was a

58 Yukkunbonbujŏnghun'gamshil, Chŏnghun osimnyŏnsa, 603. According to this record, six films were made in 1960; four were made between 1961 to 1963; two, between 1964 and 1966; and four, between 1967 and 1969.

59 Yukkunbonbujŏnghun'gamshil, Chŏnghun osimnyŏnsa, 828-829.

60 Yukkunbonbujŏnghun'gamshil, Chŏnghun osimnyŏnsa, 829. With participation from soldiers in active service and generous support from the army regarding ammunition and bombs, Fellow Soldiers was mainly filmed on locations, In 1975, it received the prime ministerial award and was popular among the people. Fellow Soldiers was remade in 1983 and again by KBS in 2010 with the English title Leg- 
popular anti-communist drama that gained a huge following among the viewers.

\section{Increase in the Number of Equipment and Vitalization of Production}

Founded in 1963, the AMPPC produced films in various genres - including newsreels, culture films, and fiction films- and became a mass production house, creating over 100 films every year.

Until the 1960s, the military film production facilities were in fact much too inadequate. With the establishment of the sound recording studio in P'ildong and the production center in 1955, the military was in charge of the postproduction processes for Korean commercial films at the time, but after the fire at the sound recording studio $\mathrm{n}$ P'ildong in 1961 until the establishment of the AMPPC, it was impossible to carry out the postproduction process, including sound recording and film development. ${ }^{61}$ The facilities and the budget of the AMPPC became realistic around the time of the Vietnam War and the Korean military's participation, spurring the need to promote the military to the people. Even though the Film Unit dispatched to the Vietnam War began its activities in September 1964, the unit had to receive support from the U.S. military or the Vietnam AMPPC even until 1967 due to the lack of films. ${ }^{62}$ However, starting in 1967, a realistic budget necessary for the production of military films began to be provided, which allowed for the purchase of projectors and lights. Also, a sound recording studio was created within the AMPPC under the leadership of Yang Chunam, who was active in all parts of the film industry, including directing, sound recording, and editing, since the colonial times under the Japanese rule.

end of the Patriots.

61 Yukkunbonbujŏnghun'gamshil, Chŏnghun osimnyŏnsa, 17-18.

62 Yi Chunsŏng, “Ch'uŏk-ŭi p'eijitŭl—chonggun 40nyŏn-ŭl toetorabomyŏ (Pages of remembrance-looking back on the forty years of following the army)," Kunyŏnghwa sasimnyŏnsa, 137. 
With the relocation of the AMPPC from P'ildong to Yŏngdŭngp'o in 1970 , the center became more vigorous, producing existing newsreels, such as the National Defense News and Vietnam's Front Lines (Wŏrnamchŏnsŏn), as well as Korean Flag Bearers (Paedar-ŭi kisu). Starting at this time, equipment such as projectors and sound recorders were improved and reinforced every year, allowing for reorganization of the production environment. As can be seen in Table 1, cameras, editors, sound recorders, automatic film developers, and other equipment began to be provided from the early 1970s, and a color film production system was installed after the AMPPC relocated from Mullaedong in Yŏngdŭngp'o to Yongsangu in 1975. In addition, starting with the production team of the Korean Flag Bearers, people involved in productions- from directors and cameramen to lighting technicians, prop designers, and actors - became government employees from 1979, providing a stable base for film production

Looking at the films produced by the AMPPC at this time, newsreels were produced at the outbreak of the Vietnam War. The AMPPC dispatched a film unit to Vietnam in September 1964 to capture the Vietnam War on camera and began to produce the National Defense News and Vietnam's Front Lines in 1966. The production of the National Defense News had been suspended at the end of 1956 but was resumed as a weekly newsreel starting with episode no. 1 in January $1966 .{ }^{63}$ For a whole year during 1966, the National Defense News was aired live through KBS, which had begun its nationwide broadcast. ${ }^{64}$ Afterward, the National Defense News was screened for the soldiers through a portable projector

63 A total of 52 episodes of the National Defense News was produced in 1966; 51 in 1967; 65 in 1968; and 39 in 1969. Starting in 1970, a total of 52 episodes were created every year, totaling 708 up to and including 1979. Among them, approximately 300 have been made available on the Defense Media Agency website (12 films) and the Modern and Contemporary Korean Historical Film Archive website (about 290 films). With the founding of the KFN TV on December 1, 2005, the series was changed to a daily TV news format.

64 Kukpangbuhongbogwalliso, Kunyŏnghwa sasimnyŏnsa, 19, 32. 
Table 1. Increased Facilities and Equipment at the ROK Army Motion Picture Production Center (AMPPC) ${ }^{65}$

\begin{tabular}{c|l}
\hline Year & \multicolumn{1}{c}{ Additional Equipment (count) } \\
\hline 1963 & Imo camera (4), Arriflex camera (1) \\
\hline 1965 & Imo camera (4), tungsten lights (8) \\
\hline 1970 & $35 \mathrm{~mm}$ National projector (2), Victor projector (10) \\
\hline 1971 & $\begin{array}{l}\text { 35mm Arriflex camera (1), 16mm Filmo movie camera (1), editor (1), Nagra } \\
\text { sound recorder (2), Akai sound recorder (1), 16/35mm Korean-made black and } \\
\text { white automatic film developer (1) }\end{array}$ \\
\hline 1972 & Arriflex camera (3), 16mm Filmo camera (12) \\
\hline 1973 & $\begin{array}{l}16 / 35 m m \text { automatic printer (1/1), console sound recording equipment (1), editing } \\
\text { equipment(1) }\end{array}$ \\
\hline 1975 & Arriflex camera (1) \\
\hline 1976 & $\begin{array}{l}\text { Automatic positive color film developer (1), automatic negative color film devel- } \\
\text { oper (1), color printer (1), color calibrator (1) }\end{array}$ \\
\hline 1977 & $\begin{array}{l}\text { Film developer (1), color printer (1), 16mm color image reducer (1), special ef- } \\
\text { fects printer (1), animation camera (1), 16mm Filmo camera (1) }\end{array}$ \\
\hline 1978 & Canon camera (10), Moviola editor (1) \\
\hline 1979 & $\begin{array}{l}\text { 16mm BL camera (2), 16/35mm Moviola editor (1/1), 16 mm high-speed check } \\
\text { projector (1) }\end{array}$ \\
\hline
\end{tabular}

in the barracks. Vietnam's Front Lines was a newsreel made for the theaters, coordinated with the dispatch of the Korean military to Vietnam in 1965. According to Yi Chunsŏng, who served in the Vietnam War as the director of Vietnam's Front Lines, initially the production team involved in the National Defense News worked on Vietnam's Front Lines. Starting in 1968, however, five to six film crew made up of soldiers in active duty were dispatched ${ }^{66}$ to film and send the videos from Vietnam, and the AMPPC was in charge of postproduction. A total of 125 films were created from 1966 to 1975, but Vietnam's Front Lines became recommended as cultural newsreels, mandatorily screened prior to feature-length films, and therefore were screened in theaters. ${ }^{67}$

65 This table is a compilation of information from pages 17 to 30 of The Forty-year History of Military Films .

66 Yi Chunsŏng, “Ch'uŏk-ŭi p'eijitŭl,” Kunyŏnghwa sasimnyŏnsa, 138.

67 Park Sun Young, "P’ŭreim sok-ŭi chŏnjaeng," 273-274. 
Aside from these two newsreel series, Korean Flag Bearer was a major film produced by the AMPPC starting in 1970. The Korean Flag Bearer series was originally designed as a series of television films, and one episode was aired every week in the form of a fiction film, documentary, or newsreel. It was created when Pak Chunghŭi (Park Chung-hee) saw a video of the North Korean army's training on North Korean TV during his inspection of the front lines and gave a special order to "utilize television to enhance anti-Communist ideology and create solidarity between the military and civilians alike." ${ }^{, 68}$ At the time, three terrestrial television networks (KBS, MBC, and TBC) simultaneously aired Korean Flag Bearer during prime time on Saturday evenings, ${ }^{69}$ which led to the heyday of anti-Communist television dramas and documentaries for nearly two decades. ${ }^{70}$ The Korean Flag Bearer series were 10-minute long videos, of which over 75 percent were directed by Yi Chunsŏng. Other participating directors were affiliated with the AMPPC, such as Yi Yŏngsil and Pak Chŏngsu. Produced in black and white, Korean Flag Bearer became a color film in November $1979 .^{71}$

The films that are classified as "educational films" or culture films in The Forty-year History of Military Films include various fiction films, documentaries, and newsreels, with running times from 10 minutes to 60

68 Yi Chunsŏng, “Ch'uŏk-ŭi p'eijitŭl," Kunyŏnghwa sasimnyŏnsa, 141.

69 The Korean Flag Bearers series was aired in the evenings on weekends until 1987, when the broadcasting workers' union was created and raised issues, prompting the abolition of the program on MBC in 1988 and KBS in 1989. A total of 1,020 episodes of the series were created until 1990, and approximately 400 episodes are available on the Defense Media Agency website.

70 In Kunyŏnghwa p'yŏllam, the Korean Flag Bearer series has been categorized as promotional films for people, and the titles of the individual episodes have been logged without the overarching series name.

71 Kim Sŏnghwa, “Ajikto saengsaenghan 3kaji sagŏn-yŏnghwabu 13nyŏn-ŭl torabomyŏnsŏ (Three still vivid incidents-looking back on the 13 years at the Film Department)," Kunyŏnghwa sasimnyŏnsa, 151. Then in the 1980s, the films became lengthier to 15 minutes, 40 minutes, and 60 minutes. 
minutes. The list includes newsreels, such as Our Strength, as well as documentaries with reedited videos from the Korean War, such as Bloody June 25 (P'imudŭn June 25) (Kim Suyong, 1960). Feature-length fiction films, such as Leaving the Fatherland (Tugo on sanha) (Yi Kangch'ŏn, 1962), starring top celebrities of the time, were also classified as "educational films." According to these standards, a total of 130 educational films were made from 1960 to $1979 .^{72}$ Among the films on this list, aside from about three films-Leaving the Fatherland, The Bridge the Boy Returned To (Sonyŏn-i toraon tari) (Yi Manhŭi, 1970), and 4 o'clock, 1950 (1950nyŏn 04si) (Yi Manhŭi, 1972) that are classified as "patriotic fiction films" in The Chronology of Military Films-most films until the mid1970s were made by directors affiliated with the AMPPC, such as Pak Chŏngsu and Pyŏn Sŏnghwan. While 10- to 20-minute short films accounted for the majority of educational films until the early $1960 \mathrm{~s}, 30$ - to 40-minute-long medium-length films began to be made in the late 1960s, and 50- to 70-minute-long feature-length films were mainly produced after the mid-1970s. In the 1970s, directors who were active in the commercial film industry, such as Kang Minho, Kim Sihyŏn, and Sŏl T'aeho produced military films, and popular film actors, including Chang Tonghŭi, Hwang Hae, Pang Suil, Kim Hŭira, Pak Am, Yi Taeyŏp, Kim Sŏkhun, Namgung Won, and Shin Iryŏng, frequently began to star in military films. Television stars, such as No Chuhyŏn, Yi Nakhun, and Kim Musaeng also starred in military films in the late 1970s.

Among these films, Advance Guards in the Jungle (Millim-ŭi ch'ombyŏng) (Pak Chŏngsu, 1969) received the Culture Film Award from the 7th Blue Dragon Film Awards, hosted by the Chosun Ilbo, and the Special Award from the 7th Korean Theater and Film Awards, hosted

72 Kunyŏnghwa p'yŏllam does not include newsreels in educational films, and the three feature-length commercial films - Leaving the Fatherland, The Bridge the Boy Returned To (Yi Manhŭi, 1970), and 4 o'clock, 1950 (1950nyŏn 04si) (Yi Manhŭi, 1972) - are classified as "patriotic fiction films." Therefore, according to this book, only 69 educational films have been created in the same period. 
by the Hankook Ilbo. The Bridge the Boy Returned To also received the Best Planned Film at the 8th Blue Dragon Film Awards, and 4 o'clock, 1950 also received the Best Culture Film Award at the Blue Dragon Film Awards. $^{73}$

\section{Conclusion: The Significance of the Production of Military Films}

As explained in detail above, films that were either produced by the military or supported by the military after 1948 were important assets for the fledgling Korean film industry. The military was a major official organization that actively participated in the film industry to actively propagate the country's ideology and values prior to the Korean War. Let us briefly examine the relationship between the military film industry and the Korean film industry.

Born around the same time as the Bureau of Public Information's Taehan News and the U.S. Information Service's Liberty News in 1952, National Defense News and the military film production center were special "laboratories" that provided workspaces for Korean film industry professionals and oversaw postproduction for commercial films at a time

73 In addition, The Bulwark of Safeguarding the Nation (Hoguk-ŭi kansŏng) (Pak Chŏngsu) received a silver medal at the 3rd Switzerland Military Film Festival (1983); Black Beret (Kŏmŭn bere) (Pak Chŏngsu) received a silver medal at the 4th Switzerland Military Film Festival (1984); Morning Bugle (Kisang nap'al) (Kang Hyŏn) received the first prize at the 3rd Italian Military Film Festival (1992); My Uncle (Uri chagŭn apŏji) (Yi Chungu) received the Best Artwork at the first Hungarian Military Film Festival (1993); I Like a Commander with a Broad Chest (Kasŭm-i nŏrbŭn sodaejang-i chotta) (Kang Myŏngjun) and Marine Spirit (Haebyŏnghon) (Han Kiho) received the gold prize at the 6th Italian Military Film Festival (1995); and The Eyes of DMZ (DMZ-ŭi nuntongja) (Han Kiho) received the Best Film Award at the 7th Italian Military Film Festival (1996). Refer to "Susang chakp'um (Award-winning works)," Kunyŏnghwa p'yŏllam. 
when the film industry was nearly nonexistent. In particular, as we can see from the example of the production of color films, which had been suspended previously, through National Defense News the Military Motion Picture Studio was an active producer that recorded significant progress in Korean film history through technical experiments at a time when the infrastructure for the film industry had disintegrated. Many Korean film industry professionals worked for the Film Unit of the Troop Information and Education Bureau at the Ministry of National Defense and the military film production center in the $1950 \mathrm{~s}$, and their production skills were also transferred to military films. ${ }^{74}$ In the mid-1950s, with increasing policy and physical support for the growth of Korean films such as the tax exemption on Korean films and the enactment of the Outstanding Film Compensation policy, most film industry professionals who worked in the military returned to the realm of fiction films. However, some re-

74 Most film industry professionals during the war were affiliated with the U.S. Information Service, Ministry of National Defense, Army Headquarters, or the Office of Troop Information and Education. According to Yi Yŏngil, people who were affiliated with the U.S. Information Service began to produce Liberty News in Chinhae. They included: (photography) Im Pyŏngho, Im Chinhwan, and Pae Sŏnghak; (film development) Kim Pongsu, Kim Hyŏnggŭn, Sŏ Ǔnsŏk, and Yi T'aesŏn; (sound recording) Yi Kyŏngsun, Ch'oe Ch'ilbok, and Yang Hubo; (editing) Kim Hŭngman and Kim Yŏnghŭi. Those who were affiliated with the Bureau of Public Information were An Chonghwa, Pak Hongrae, Yi Kyŏngsun, and Kim Hŭngman, while those who belonged to the Ministry of Defense's Troop Information and Education Bureau included photography directors Yang Chunam, Kim Ch'angsu, Kim Haksŏng, Hong Ilmyŏng, Shim Chaehŭng, Yang Pohwan, Kim Poch' ŏl, Kim Tŏkjin, Yi Sŏngch’un, Pyŏn Injip, Yŏm Hwach’un, No Hŭisam, and Hŏ Min, as well as editing technician Kim Hŭisu. Film industry professionals in the Korean Air Force's Office of Troop Information and Education were directors Hong Sŏnggi and Shin Sangok, actors Chŏn T'aegi, Kim Ilhae, No Kyŏnghŭi, and Hwang Nam. Officer Chŏng Inyŏp was in charge of photography at the time as well as sound recording and developing. The Korean Navy had a film unit spearheaded by Yi P'iru. Yi Yŏngil, Han'guk yŏnghwa chŏnsa, 227-228. Meanwhile, Director Kim Suyong moved from military films to commercial fiction films, while Director Yang Chunam moved from commercial films into military films.. 
mained at the military film studio to continue their film career or switched back and forth between military films and commercial films until they finally settled down in the commercial film industry in the 1960s. For instance, Ch'oe Ch'ilbok, a sound recording technician who was affiliated with the U.S. Information Service, came to work at the military film studio in 1955; Kim Hŭisu started his film career at the military film studio in 1953 where he remained until finally moving to the fiction film industry in the late 1950s; Yang Hubo worked in both the AMPPC and the commercial film industry until the 1960s.

The military film industry and the commercial film industry continued to maintain a close relationship with human resource exchanges in the 1960s and the 1970s. Director Kang Minho moved to work for the AMPPC after directing the educational film Bloodied Communications Cable (P'iro muldŭn yusŏnchul) in 1972, and the production staff including directors Kim Sihyŏn and Sŏl T'aeho frequently came back to the AMPPC to direct medium- to feature-length educational films. Moreover, directors Ch'oe Hawŏn, Ko Yŏngnam, and Pak Ch'ŏlsu, screenwriters Ch’oe Sŏkkyu, Yi Chŏnggŭn, An Chinwŏn, Yi Hyŏngu, Yi Ch’an'gyu, Yi Chunghŏn, Paek Kyŏl, and Kim Kangyun, Director of Photography An Myŏnhŭi (who also directed I Hate Men (Namjanŭn sirŏ) (1967)), animator Yun Ch'ungguk (who was in charge of photography at the AMPPC), special effects technician Yi Mun'gŏl, developer Yang Hŭich'ŏl, as well as a large number of Korean actors previously mentioned participated in the production of military films during this time. ${ }^{75}$ Actively engaging with the mainstream commercial film industry, the AMPPC provided a base for Korean film industry professionals to gain experience and pro-

75 Yi Chunsŏng, "Ch'uŏk-ŭi p'eijitŭl” in Kunyŏnghwa sasimnyŏnsa; Pak Chŏngsu, "Angke-ŭi yŏngungdŭl (Anke's heroes)" in Kunyŏnghwa sasimnyŏnsa; Han'guk yŏnghwasa yŏn'guso (Korean Film History Research Center), "Yi Mun'gŏl," in Han'guk yŏnghwa-rŭl marhanda: Han'guk yŏnghwa-ŭi rŭnesangsŭ (Talking about the Korean Cinema: the renaissance of the Korean Cinema) 2, ed. Han'guk yŏngsang charyowŏn (Korean Film Archive) (Seoul: Korean Film Archive, 2006), 294336. 
duce films in the 1970s and afterward.

The production of military films also had an impact on anti-Communist films and anti-Communist television programs in its early years. Various military films produced from the 1950s to the 1970s, including the antiCommunist films produced in the military since 1948 and the first war documentary An Assault of Justice, were utilized in anti-Communist films for theaters as well as television news, drama series, and documentaries. These films were the archetype for each derivative program format. In addition, with the support of the military, it was possible to direct and capture realistic scenes for anti-Communist and war films, which also contributed to the development of the Korean film industry.

It is also important to recognize the significance of the "militaristic" utilization of military films. Above all, the military films' most important role in its history since the founding of the government of the Republic of Korea was its utilization as part of the Korean government's psychological warfare waged against its people between the 1950s and 1970s under the Cold War regime. As examined in this paper, it is particularly significant that military films that were produced in 1948 and 1949 tend to focus on the Yŏsu-Sunch'ŏn Incident, regardless of the genre of the film. Accompanied by extensive promotional advertisements, these films continued to be produced as part of the military's information and educational efforts to define the identity of the Republic of Korea and its people by dividing the people who were ideologically communist (non-citizens) or anti-communist (citizens).

The role of military films as propaganda warfare, which became much more explicit with the outbreak of the Korean War, became strengthened through the installation of the AMPPC in 1963, the dispatch of Korean soldiers for the Vietnam War, and the improvement of the film production environment in 1965. Particularly with the dispatch of Korean troops to Vietnam, it became important for the government to produce and screen military films as propaganda and justification for Korea's participation in the war. As a result, the National Defense News was aired nationwide for an entire year in 1966, infiltrating people's daily lives with images of the 
war. In addition, Vietnam's Front Lines, which was produced every month during the same year and distributed and screened in theaters nationwide through the mandatory screening policy, provided vivid scenes of battle as "entertainment" for the viewers, etching the image of victory into the people's minds. Moreover, Korean Flag Bearers, which was broadcast on television on the weekend during primetime through all three terrestrial television networks starting in the 1970s also evoked memories of the Korean War along with the images of the Vietnam War, strengthening Cold War sentiments. Therefore, while the Yushin Constitution in 1972 and the oppressive control mechanisms that led to the implementation of Yushin film suppressed the quantitative and qualitative growth of Korean films that had continued in the previous 15 years, the military film industry became much more vibrant. In the 1970s, the AMPPC, which continued to reinforce the Cold War by placing significance on the Vietnam War throughout and even after the war, was able to produce over 130 films in various genres and lengths every year.

This paper attempts to reorganize the history of military films from 1948 to 1979 by examining and comparing various writings, oral records, memoirs, newspaper articles and advertisements, and also discusses the industrial and military significance of military films. Although I was unable to verify the existing materials in its entirety or provide even more evidence, this paper is significant in that it systematically organized the history of the military film industry, which had not been properly explained in the past, and it discusses the military film industry as a means to examine the overall structure of the film industry and its vibrant activities at the time. As clarified in the introduction, this discussion was performed as a basis for the analysis of specific military films. I hope to delve further into the significance and the role of military films as a tool of propaganda warfare through textual analysis in future studies. 


\section{References}

\section{Chayu shinmun}

2. Chosŏn ilbo

3. Hankuk ilbo

4. Kyŏnghyang shinmun

5. Tonga ilbo

6. Kukpanghongbowŏn (Defense Media Agency), Kukpang hongbo 65nyŏnsa (The 65 Years of National Defense Promotion). Seoul: Kukpanghongbowŏn, 2015.

7. Kunyŏnghwa p'yŏllam: 1950-1994, (The Chronology of Military Films: 1950-1994). Seoul: Kukpangbuhongbogwalliso, 1997.

8. Kukpangbuhongbogwalliso (Defense Media Management Center), Kunyŏnghwa sasimnyŏnsa (The Forty-year History of Military Films). Seoul: Kukpangbuhongbogwalliso, 1992.

9. Yukkunbonbujŏnghun'gamshil (Army Headquarters' Office of Troop Information and Education), Chŏnghun osimnyŏnsa (The Fifty-year History of Troop Information and Education). Seoul: Kukpangbuhongbogwalliso (Defense Media Management Center), 1991.

10. Han'guk yŏngsang charyowŏn (Korean Film Archive) Database(KMDb). Accessed November 28, 2018. http://kmdb.or.kr

11. Koryŏtaehakkyo Han'guk kŭnhyŏndae yŏngsang akaibŭ (Modern and Contemporary Korean Historical Film Archive). Accessed November 28, 2018. http://kfilm.khistory.org

12. Kukpanghongbowŏn (Defense Media Agency). Accessed November 28, 2018. http://tv.dema.mil.kr/web/tv/main.do

13. Ch'a, Ch'anghun, "Kukkunbangsong (KFN) midiǒ hwaryongbangan yŏn'gu: chanbyŏnggyoyuk, wigidaeŭngch'aek, chŏngch'aekhongbo unyŏngbangan-ŭl chungshimŭro (A study on the use of the Korea Forces Network media: focusing on the operation of soldier training, emergency response, and policy promotion activities)." MA diss., Korea University, 2014.

14. Han'guk yŏnghwasa yŏn'guso (Korean Film History Research Cen- 
ter), Han'guk yŏnghwa-rŭl marhanda: Han'guk yŏnghwa-ŭi rünesangsŭ (Talking about the Korean Cinema: the renaissance of the Korean Cinema) 2, edited by Han'guk yŏngsang charyowŏn (Korean Film Archive), Seoul: Korean Film Archive, 2006.

15. Im, Songja, "Yŏsunsagŏn ihu sŏnmugongjak-ŭl chungshimŭro pon Chirisanjigu-ŭi ppalch'isan chinap (Suppression of partisans in Mt. Jiri District: focusing on the placation maneuver after the Yŏsun Incident)." Han'guk kŭnhyŏndaesa yŏn'gu (Journal of Korean Modern and Contemporary History) 81 (June 2017): 183-213.

16. Kim, Chongmyŏng, “2006-2010nyŏn kukkunpangsong TV 5nyŏn-e taehan p'yŏngga-wa che'an (An evaluation of Korean KFN TV's performance from 2006 to 2010 and suggestions for its future development." MA diss., Dankuk University, 2011.

17. Park, Sun Young, "P’ŭreim sok-ŭi chŏnjaeng: kungnip yŏnghwa chejakso-wa kukkun yŏnghwa chejakso-ŭi Bet'ŭnam chŏnjaeng yŏnghwa-rŭl chungshimurro (A war in the frame: focusing on the films about the Vietnam War produced by the National Film Production Center and the AMPPC)." in Yŏngsang-kwa akaibing kŭrigo saeroun yŏksa ssŭgi (Videos, archiving, and the writing of a new history), edited by Hŏ Ǔn, Seoul: Tosŏch'ulp'an Sŏnin, 2015.

18. Shim, Hyegyŏng, "Chuhanmigongbowŏn yŏnghwagwa-ŭi chejak hwan'gyŏng-gwa hwaryakhan Han'guk yŏnghwain-dŭl: haebangesŏbutŏ 1960nyŏndaekkaji (The production environment of the US Information Service' Film Department and the Koreans Who Played an Active Part: from Korea's liberation to the 1960s)." in Han'guk yŏngsang charyowŏn 2011nyŏn sujippogwŏnchŏn charyojip: naengjŏn shidae Han'guk-ŭi munhwayŏnghwa-T'edŭ Konŏnt'ŭ, Hŏmp'ŭri Renji k'ollecshyŏn-ŭl chungshimüro (Sourcebook of the Korean Film Archive's 2011 Collection and Restoration Exhibition: Korean culture films during the Cold War-focusing on the Ted Conant and Humphrey Leynse collections), edited by Han'guk yŏngsang charyowŏn (Korean Film Archive), Seoul: Korean Film Archive, 2011. 
19. Yi, Shinjae, “Chuwŏl Han'gukkun pangsongguk (KFVN) ŭi sŏlch'iwa unyŏng (A study on the establishment and operation of the Korean Forces Vietnam Network)." Kunsa (Military History) 92 (September 2014): 65-101.

20. Yi, Yŏngil, Han'guk yŏnghwa chŏnsa (A complete history of Korean films) (revised and enlarged edition). Seoul: Tosŏch'ulp'an Sodo, 2004. 


\section{The History of the Military Film Industry - From the inception of military films to the ROK Army Motion Picture Production Center (1948-1979) -}

This paper examines the history of the ROK Army Motion Picture Production Center (AMPPC), which played a significant role in the Korean film industry from the 1950s to the 1970s. Around this time, the AMPPC was an official film production institute alongside the National Film Production Center, and produced newsreels and culture films as well as fiction films. Starting with the documentary An Assault on Justice, the first film on the Korean War, and the National Defense Series, the AMPPC produced educational short films and many feature-length films. It was a large-scale film production company that produced an average of over 100 films a year until the 1970s.

In addition, the military film industry provided workspace for Korean film industry professional and took care of postproduction for commercial films at a time when the film industry was considered nearly impossible. It was also an active producer that recorded significant progress in the Korean film history through technical experiments at a time when the infrastructure for the film industry had collapsed. In addition, many Korean film industry professionals were affiliated with or closely related to the center. Not only directors but also people in photography, editing, and screenwriting worked in both the mainstream film industry and the AMPPC. Moreover, military films also had a certain impact on antiCommunist films and anti-Communist television programs in its early years. Various military films produced from the 1950s to the 1970s, including the antiCommunist films produced in the military since 1948 and the first war documentary An Assault of Justice, were utilized in anti-Communist films for theaters but also television news, drama series, and documentaries, becoming archetypes for 
each derivative program format. In sum, the AMPPC during this time was closely related to the Korean film industry as well as the television industry in terms of quantity and quality, providing the human resources and physical basis.

It is also important to imbue significance into the "militaristic" utilization of military films. Above all, the military films' most important role in its history since the founding of the government of the Republic of Korea was its utilization as part of the Korean government's psychological warfare waged against its people between the 1950s and 1970s under the Cold War regime. The role of military films as propaganda warfare, which became much more explicit with the outbreak of the Korean War, became strengthened through the installation of the AMPPC in 1963, dispatch of Korean soldiers for the Vietnam War and the improvement of the film production environment in 1965. Particularly with the sending of Korean troops to Vietnam, it became important for the government to produce and screen military films as propaganda for Korea's unjustified participation in the war. In the 1970s, the AMPPC, which had to continue the Cold War by continuously placing significance on the Vietnam War throughout and even after the war, was able to produce over 130 films in various genres and lengths every year.

This paper is significant in that it systematically organizes the history of the military film industry, which had not been properly explained in the past, and that it discusses the military film industry as a means to examine the overall structure of the film industry and its vibrant activities at the time. This discussion has been performed as a basis for the analysis of specific military films. I hope to delve further into the significance and the role of military films as a tool of propaganda warfare through textual analysis in future studies.

Keywords: ROK Army Motion Picture Production Center (AMPPC), military films, Cold War, Vietnam War, psychological warfare 


\section{〈국문초록〉}

\section{군영화산업의 역사 \\ - 군 영화의 시작부터 국군영화제작소까지(1948 1979)-}

박선영 (고려대학교)

이 글은 1950년대부터 1970년대까지 한국영화산업의 중요한 한 축을 담당하고 있었 던 국군영화제작소의 역사를 살펴본다. 이 시기 국군영화제작소는 국립영화제작소와 더불어 국가의 공식적인 영화 제작기관으로, 다양한 뉴스영화와 문화영화, 그리고 극영 화를 제작했다. 최초의 6.25 전쟁영화였던 다큐멘터리 <정의의 진격>과 <국방뉴스>를 시작으로, 국군영화제작소는 교육용 단편영화와 다수의 장편 극영화를 비롯하여 1970 년대까지 한 해 평균 100 여 편의 영화를 제작하는 대규모 영화사였다.

또한, 1950년대 군 영화는 민간 영화산업이 거의 불가능했던 당시, 한국영화인들의 작업 공간이자 상업 영화의 후반작업까지 담당했다. 한국영화 기반시설이 붕괴되었던 시기에 기술적 실험을 통해 한국영화사의 의미 있는 진보를 이루었던, 적극적인 제작 의 주체이기도 했다. 뿐만 아니라 한국영화사의 주요 인물들이 여기에 소속되어 있었 거나 밀접한 연관을 맺고 있었다. 연출뿐 아니라 촬영, 편집, 시나리오 등에 종사했던 다수의 영화 인력들도 주류 한국영화 산업과 국군영화제작소를 오가며 활약했다. 이에 더하여 군 영화는 반공영화 및 TV의 초기 반공 프로그램에도 일정한 영향을 미쳤다고 볼 수 있다. 1948년 이후 군에서 제작한 반공영화들과 최초의 전쟁 다큐멘터리 <정의 의 진격>을 비롯하여 1950-70년대에 제작되었던 다양한 군영화들은 이후 극장용 반공 영화뿐 아니라 TV뉴스와 TV드라마 등으로 활용되면서 각 프로그램 포맷의 원형이 되 었다. 요컨대, 이 시기 국군영화제작소는 양적인 측면이나 질적인 측면에서, 인력과 물 적 토대의 측면에서 한국의 영화산업 및 TV산업과도 밀접한 관련을 맺고 있었다.

한편, 군영화의 ‘군사적' 활용에 대해서도 더 적극적인 의미 부여가 필요하다. 무엇 보다, 1950-70년대 전 세계적 냉전 체제 하에 놓인 한국의 ‘군영화'가 자국민들을 향한 심리전의 일환으로 활용되었던 것은 대한민국 정부 수립 이후, 군영화의 역사와 함께 지속되어 온 가장 중요한 역할이었다. 한국 전쟁을 기점으로 더욱 노골화되었던 '선전 전'으로서의 군영화의 역할은 1963년 국군영화제작소의 설치, 1965년 베트남전 파병과 제작환경의 개선 등의 계기를 통해 한층 강화되었다. 특히 베트남전 파병을 둘러싸고, 
명분 없는 참전에 대한 대국민 선전전으로서의 군사영화의 제작과 상영이 중요해졌다. 베트남 전쟁이 지속되는 동안, 그리고 전쟁이 끝난 뒤에도, 이 전쟁에 대한 지속적인 의미 부여를 통해 '냉전'을 영속화할 필요가 있었던 1970년대 국군영화제작소는 그 어 느 시기보다 다종다기의 영화들을 매년, 130 여 편씩 생산할 수 있었다.

이 글은 지금까지 제대로 서술되지 못했던 군영화산업의 역사를 체계적으로 정리했 다는 점과 이를 당대 영화계 전반의 구조와 역동성을 보여주는 과정으로 논의했다는 점에서 의의를 찾을 수 있을 것이다. 이 논의는 이후, 구체적인 군 영화들의 분석을 위 한 기초 작업으로 진행되었다. 후속 연구를 통해 심리전의 도구로서 이 시기 군영화의 의미와 역할에 대하여 텍스트 분석을 통해 보다 구체적인 논의를 해 나가고자 한다.

핵심어: 국군영화제작소, 군영화, 냉전, 베트남전쟁, 심리전 